\title{
Korelasi Kadar Angiopoietin-2 Plasma dan Petanda Inflamasi Dengan Resistensi Insulin Pada Penderita Obesitas Abdominal
}

\author{
Anak Agung Gede Budhitresna
}

\author{
Bagian Penyakit Dalam Fakultas Kedokteran dan Ilmu Kesehatan Universitas Warmadewa, Denpasar \\ Rumah Sakit Umum Daerah Sanjiwani, Gianyar \\ Email:agbudhitresna@yahoo.com
}

\begin{abstract}
Abstrak
Obesitas abdominal (Ob-Ab) merupakan komponen utama resistensi insulin (RI) yaitu kekutan pendorong utama untuk terjadinya diabetes mellitus (DM) tipe-2. Kadar angiopoietin-2 (Ang-2) plasma dilaporkan mengalami peningkatan pada penderita $\mathrm{Ob}-\mathrm{Ab}$ dan diduga bahwa Ang-2 berpengaruh untuk terjadinya RI. Tujuan penelitian ini adalah untuk mengetahui korelasi kadar Ang-2, Inflamasi dan RI pada penderita $\mathrm{Ob}-\mathrm{Ab}$. Dilakukan penelitian secara cross-sectional analitik pada 81 penderita dengan $\mathrm{Ob}-\mathrm{Ab}$. Kadar TNF- $\alpha, s$ TNFR1 dan Ang-2 plasma diukur menggunakan metode ELISA. RI diukur menggunakan HOMA-IR. Analisis varian (ANOVA) dipergunakan untuk mengetahui persamaan variabel kontinyu. Analisis multivariat dipergunakan untuk mengetahui peran kadar TNF- $\alpha$, s-TNFR-1, Ang-2 terhadap RI. Model analisis jalur (path analysis) dipergunakan untuk mengetahui pengaruh faktor risiko terjadinya RI. Hasil penelitian menunjukkan bahwa kadar TNF- $\alpha$ plasma tidak berkorelasi dengan HOMA-IR, sedangkan sTNFR-1 dan Ang -2 plasma berkorelasi positif bermakna dengan HOMA-IR (masing-masing $r=0,323 ; p=0,003$ dan $r=0,641$; $\mathrm{p}=<0,001)$. Pada analisis multivariat ditemukan Ang-2 merupakan faktor bebas berhubungan dengan HOMAIR $(\mathrm{p}=<0,001)$. Kadar Ang-2 plasma yang tinggi merupakan faktor dominan $(64,1 \%, \mathrm{p}=<0,001)$. Simpulan: pada penderita $\mathrm{Ob}-\mathrm{Ab}$ kadar Ang-2 berkorelasi dengan terjadinya RI dan inflamasi.
\end{abstract}

Kata kunci: Ang-2, resistensi insulin, inflamasi, obesitas abdominal.

\section{Abstract \\ [Correlation of Plasma Angiopoietin-2 and Inflammation Marker with Insulin Resistence in Patients with Central Obesity]}

Abdominal obesity (Ab-Ob) is a central component of insulin resistance (IR) and it is suggested that IR is a driving factor in the development of type 2 diabetes mellitus (T2DM). Plasma Ang-2 levels have been reported to increase in the Ab-Ob and it has been hypothesized that Ang-2 plays important role in the occurrence of IR. We assessed the relationship between plasma Ang-2 levels, Inflammation and IR in Ab-Ob. A cross-sectional analytic study on 81 abdominally obese subjects was performed. The concentrations of TNF- $\alpha$, sTNFR1 and Ang-2 plasma were measured using ELISA method. IR was measured using HOMA-IR. Analysis of variance (ANOVA) was used to test the equality of continuous variables. Multivariate analyses were performed to examine the influence of TNF- $\alpha, s-T N F R-1$, and Ang-2 on IR. Path analysis models were performed to assess the influence of risk factors on occurrence of IR. Plasma of TNF- $\alpha$ was not correlated with HOMA-IR $(r=160 ; p=0.154)$ whereasTNFR-1 and Ang-2 were significantly positive correlated with HOMA-IR $(r=0.323, p=0.003$ and $r=0.641, p=<0.001$, respectively). The multivariate analysis showed Ang-2 was independently associated with HOMA-IR $(p<0.001)$. It was found that high Ang-2 level was a dominant risk factor (64.1\%, $p=<0.001)$ for influencing IR in the abdominally obese subjects. It is concluded that plasma Ang-2 level is correlated with occurrence of IR and inflammation in abdominally obese subjects.

Keywords: Ang-2, insulin resistance, inflammation, abdominal-obesity.

\section{PENDAHULUAN}

Resistensi insulin (RI) merupakan komponen sentral sindroma metabolik (SM) yang meliputi obesitas abdominal ( $\mathrm{Ob}-\mathrm{Ab})$, hipertensi, intoleransi glukosa, dislipidemia, DM tipe 2, keadaan proinflamasi dan protrombosis. $^{[1,2]}$ Berbagai penelitian melaporkan inflamasi berkorelasi kuat dengan timbulnya RI yang menghubungkan antara obesitas dan DM tipe $2 .^{[3,4]}$ Adiposit dan makrofag dapat sebagai sumber sitokin proinflamasi yang mengaktivasi jalur 
inflamasi pada sel-sel jaringan adiposa yang bersifat parakrin atau autokrin. ${ }^{[5]}$ Obesitas berhubungan dengan inflamasi kronis dan angiogenesis yang memberikan asupan nutrisi dan oksigen sebagai respon terhadap bertambahnya jaringan adiposa. ${ }^{[6]}$ Hipoksia merupakan stimulus utama terjadinya inflamasi dan angiogenesis melalui peningkatan ekspresi hypoxia inducible factor (HIF), yang kemudian akan meningkatkan transkripsi gen-gen angiogenik seperti vascular endothelial growth factor (VEGF) dan angiopoietin (Ang). ${ }^{[7]}$ Ang-1 dan Ang-2 diperlukan untuk pembentukan pembuluh darah. Baik Ang-1 maupun Ang-2 bekerja melalui ikatan dengan reseptortirosin kinase-2 (Tie-2): Ang-1 mempunyai efek agonis terhadap Tie -2 melalui reseptor autofosforilasi yang diperlukan untuk stabilitas pembuluh darah sedangkan Ang-2 mempunyai efek antagonis melalui hambatan signaling Ang1/Tie-2. ${ }^{[8]}$ Hilangnya signaling Tie-2 akan merusak endotelium dan memfasilitasi respon angiogenik dan inflamasi terhadap sitokin TNF- $\alpha .{ }^{[9]}$

Reseptor Ang-2 dan Tie-2 berperan pada patofisiologi beberapa penyakit inflamasi dan vaskuler. Tabata et al. melaporkan baik pada manusia maupun pada hewan percobaan, konsentrasi Ang-2 berkorelasi dengan adipositas, RI sistemik, dan inflamasi. ${ }^{[10]}$ Meskipun dari penelitian terakhir dilaporkan bahwa konsentrasi Ang2 berkorelasi positif dengan konsentrasi insulin pada penderita DM tipe 2 namun mekanisme yang mendasari hubungan antara Ang-2 dengan RI pada Obesitas Abdominal (Ob-Ab) belum sepenuhnya diketahui.Penelitian ini dilakukan karena sampai saat ini belum ada data keterkaitan antara konsentrasi Ang-2 plasma dan faktor inflamasi terhadap kejadian RI pada penderita $\mathrm{Ob}-\mathrm{Ab}$.

\section{METODE}

Satu penelitian cross-sectional analitik dilakukan pada penderita $\mathrm{Ob}-\mathrm{Ab}$. Populasi terjangkau adalah penderita $\mathrm{Ob}-\mathrm{Ab}$ yang datang untuk pemeriksaan kesehatan di Rumah Sakit Umum Sanjiwani antara bulan Januari sampai dengan April 2014. Subjek penelitian adalah populasi terjangkau yang memenuhi kriteria inklusi dan eksklusi dengan teknik consecutive sampling. Subjek penelitian adalah pasien yang benar-benar mau ikut penelitian dengan mengisi informed consent setelah mendapatkan kelaikan etik dari Komite Etik Fakultas Kedokteran Universitas Udayana. Pemeriksaan status antropometri, meliputi tinggi badan, berat badan, dan lingkar perut (LP). Indek masa tubuh (IMT) diperoleh dari perhitungan berat badan dalam $\mathrm{kg}$ dibagi dengan tinggi badan dalam $\mathrm{m}^{2}$. Klasifikasi dari IMT dan LP berdasarkan Asia-Pacific perspective redefining IMT dan LP pada orang Asia dewasa. ${ }^{[2]}$ IMT diklasifikasikan sebagai: underweight $\left(<18,5 \mathrm{~kg} / \mathrm{m}^{2}\right.$, normal $\left(18,5-22,9 \mathrm{~kg} / \mathrm{m}^{2}\right)$, overweight $\left(23-24,9 \mathrm{~kg} / \mathrm{m}^{2}\right)$, obese I (25$\left.29,9 \mathrm{~kg} / \mathrm{m}^{2}\right)$, dan obese II $\left(>30 \mathrm{~kg} / \mathrm{m}^{2}\right)$, sementara kriteria untuk Ob-Ab menggunakan nilai lingkar pinggang pria $\geq 90 \mathrm{~cm}$ dan wanita $\geq 80 \mathrm{~cm}$. Diagnosis DM dibuat berdasarkan pemeriksaan kadar gula darah sebelum makan dan 2 jam setelah makan. Kriteria eksklusi penelitian adalah: penderita dengan penyakit jantung koroner, gagal ginjal akut maupun kronis, panyakit hati akut maupun kronis, infeksi, keganasan, riwayat keluarga menderita diabetes, penggunaan obat-obatan seperti insulin, hipoglikemik oral, anti inflamasi, anti hipertensi, dan hipolipidemia minimal sejak dua minggu terakhir dan penderita yang menolak ikut penelitian. Penderita yang mau ikut penelitian diberikan penjelasan tentang tujuan penelitian. Pada semua penderita dilakukan anamnesis lengkap, pemeriksaan fisik, pengumpulan data antropometri dan data demografi. LP diukur pada pertengahan antara tulang iga paling bawah dan arkus iliaka berdasarkan kriteria WHO. Setelah puasa selama 8 jam, dilakukan pengambilan darah vena untuk pemeriksaan glukosa plasma, insulin serum, dan profil lipid pada semua penderita. Pemeriksaan tekanan darah dilakukan 3 kali berturut-turut dalam posisi duduk setelah penderita istirahat selama 5 menit. Tekanan darah sistolik dan diastolik didapatkan dari 
rerata tiga kali pembacaan. Penderita dikatakan mengalami hipertensi bila tekanan darahnya $\geq 140 / 90 \mathrm{mmHg}{ }^{[13]}$

Glukosa plasma diukur dengan metode heksokinase (Hitachi 912 ${ }^{\circledR}$ ). Insulin serum diukur dengan metode chemiluminescence immunometric (Immulite $\left.{ }^{\circledR} 2000\right)$ dengan koefisien variasi intra dan inter-assay sebesar 4,2-5,8\%. Pemeriksaan ini tidak mempunyai reaksi silang yang bermakna dengan proinsulin. Kadar serum kolesterol total, kolesterol high-density lipoprotein (HDL), kolesterol low-density lipoprotein (LDL) diukur dengan metode enzimatik (Hitachi $912^{\circledR}$ ). Definisi dislipidemia ditentukan berdasarkan definisi sindrom metabolik menurut IDF.(IDF 2015). Kadar kolesterolHDL yang rendah didefinisikan bilamana kadar kolesterol-HDL $<40 \mathrm{mg} / \mathrm{dL}$ pada pria dan $\quad<50 \mathrm{mg} / \mathrm{dL}$ pada wanita; hiperkolesterolemia-LDL bilamana kadar kolesterol-LDL $>130 \mathrm{mg} / \mathrm{dL}, \quad$ dan hipertrigliseridemia bilamana kadar trigliserida $>150 \mathrm{mg} / \mathrm{dL}$. Pemeriksaan kadar Angiopoietin-2 menggunakan kit ELISA (R\&D Systems, Inc, Menneapolis, United State of America). Kadar TNF- $\alpha$ dan TNF- $\alpha$ receptor-1 (TNFR1) plasma juga diperiksa menggunakan metode ELISA (R\&D Systems, Inc, Menneapolis, United State of America). Resistensi insulin ditentukan menggunakan rumus Homeostatic Model Assessment (HOMA) yang ditemukan oleh Matthews et al. Rumus resistensi insulin adalah HOMA-IR = Insulin Plasma Puasa $(\mu \mathrm{U} / \mathrm{ml})$ X Glukosa Plasma Puasa (mmol/ L) $/ 22.5 .^{[14]}$

Sebelum dianalisis, semua data yang diperoleh diperiksa apakah berdistribusi normal atau tidak dengan menggunakan tes normalitas Kosmogorov Smirnov. Data dikemukakan sebagai means \pm standar deviasi. Analisis statistik menggunakan Statistical Package for Social Sciences (SPSS) versi 15.0. Koefisien korelasi antara kadar Ang-2 dengan beberapa parameter menggunakan uji korelasi Pearson's. Persamaan regresi multipel dipergunakan untuk mengetahui peran kadar TNF- $\alpha$, TNFR1, dan Ang-2 hubungannya dengan
RI. Nilai $\mathrm{p}<0,05$ dengan interval kepercayaan (IK) $95 \%$ dikatakan bermakna secara statistik. Model analisis Path dipergunakan untuk menganalisis pengaruh langsung maupun tidak langsung beberapa faktor risiko kejadian $\mathrm{RI}$ pada $\mathrm{Ob}-\mathrm{Ab}$.

\section{HASIL}

Sebanyak 81 penderita $\mathrm{Ob}-\mathrm{Ab}$ ikut serta dalam penelitian dengan usia rerata 49,49 $\pm 6,79$ tahun, IMT 34,14 $\pm 3,74$ dan lingkar pinggang $103,57 \pm 8,27 \mathrm{~cm}$. Dari $46 \%$ laki-laki dan $54 \%$ perempuan, rerata kadar Ang-2 adalah 1,4 $\pm 0,3 \mathrm{ng} / \mathrm{ml}$, TNF- $\alpha$ $12,59 \pm 5,29 \mathrm{pg} / \mathrm{ml}$, dan TNFR1 4,63 $\pm 2,19$ $\mathrm{ng} / \mathrm{ml}$ (Tabel 1).

Analisis korelasi diantara semua faktor-faktor risiko, didapatkan usia $(\mathrm{r}=0,697 ; \mathrm{p}<0,05)$; tekanan darah sistolik $(\mathrm{r}=0,825 ; \mathrm{p}<0,05$; tekanan darah diastolik $(\mathrm{r}=0.925 ; \quad \mathrm{p}<0,05) ; \quad$ kadar trigliserida $(\mathrm{r}=0,367 ; \mathrm{p}<0,005)$, kadar TNFR1 $(\mathrm{r}=0,323$; $\mathrm{p}<0,005)$ dan Ang-2 $(\mathrm{r}=0,641 ; \mathrm{p}<0,001)$ mempunyai korelasi positif secara bermakna dengan kejadian RI (data tidak ditampilkan).

Persamaan regresi multipel dipergunakan untuk mengetahui korelasi antara beberapa faktor risiko terhadap kejadian RI. Diantara semua faktor-faktor risiko tersebut, hanya kadar Ang-2 plasma yang mempunyai korelasi positif bermakna $(\beta=0.577 ; \quad p<0,001)$ dengan kejadian RI (Tabel 2).

Hasil penelitian ini menunjukkan bahwa RI adalah variabel tergantung, sementara TNF- $\alpha$, TNFR1, dan Ang-2 adalah variabel bebas. Namun demikian hanya Ang-2 secara langsung berpengaruh terhadap kejadian RI, sedangkan variabel lainnya berpengaruh secara tidak langsung melalui variabel lainnya. Pada model analisis Path (Gambar 1), kadar Ang-2 plasma merupakan faktor risiko utama dan konsisten $(60,10 \%, \quad p<0,001) \quad$ terhadap kejadian RI pada penderita Ob-Ab. Kadar Ang-2 plasma berpengaruh secara langsung maupun tidak langsung melalui TNF- $\alpha$ dan TNFR1 (Gambar 1). 
Tabel 1. Karakteristik 81 Penderita Ob-Ab.

\begin{tabular}{|c|c|c|c|}
\hline Variabel & Rerata \pm SD & $\begin{array}{l}\text { Medi- } \\
\text { an }\end{array}$ & Rentang \\
\hline Umur (tahun) & $49,49 \pm 6,79$ & 50,00 & $35-60$ \\
\hline $\begin{array}{l}\text { Proposisi laki-laki } \\
(\%)\end{array}$ & $46 \%$ & & \\
\hline Berat badan $(\mathrm{kg})$ & $88,27 \pm 12,37$ & 86,30 & $64,4-124,2$ \\
\hline Tinggi badan $(\mathrm{cm})$ & $160,68 \pm 7,36$ & 160,00 & $147-180$ \\
\hline IMT & $34,14 \pm 3,74$ & 33.89 & $26,82-44,95$ \\
\hline $\begin{array}{l}\text { Lingkar pinggang } \\
(\mathrm{cm})\end{array}$ & $103,57 \pm 8,27$ & 101,00 & $90-129$ \\
\hline $\begin{array}{l}\text { Tekanan darah } \\
\text { sistolik }(\mathrm{mmHg})\end{array}$ & $140,48 \pm 24,97$ & 140,00 & $110-180$ \\
\hline $\begin{array}{l}\text { Tekanan darah } \\
\text { diastolik }(\mathrm{mmHg})\end{array}$ & $81,10 \pm 12,64$ & 80,00 & $60-107$ \\
\hline $\begin{array}{l}\text { Gula darah puasa } \\
(\mathrm{mg} / \mathrm{dl})\end{array}$ & $137,52 \pm 63,09$ & 107,00 & $78-324$ \\
\hline $\begin{array}{l}\text { Gula darah } 2 \text { jam } \\
\text { p.p (mg/dl) }\end{array}$ & $196,31 \pm 104,01$ & 148.00 & $70-451$ \\
\hline $\begin{array}{l}\text { Kolesterol total } \\
(\mathrm{mg} / \mathrm{dl})\end{array}$ & $214,25 \pm 35,61$ & 208,00 & $150-341$ \\
\hline $\begin{array}{l}\text { Kolesterol - HDL } \\
(\mathrm{mg} / \mathrm{dl})\end{array}$ & $45,68 \pm 7,18$ & 45,00 & $27-63$ \\
\hline $\begin{array}{l}\text { Kolesterol - LDL } \\
(\mathrm{mg} / \mathrm{dl})\end{array}$ & $138,02 \pm 28.51$ & 135,00 & $83-214$ \\
\hline Trigliserida (mg/dl) & $160,65 \pm 61,88$ & 156,00 & $70-374$ \\
\hline Insulin $(\mu \mathrm{IU} / \mathrm{ml})$ & $7,408 \pm 4,21$ & 6,70 & $2-22$ \\
\hline HOMA- IR & $2,41 \pm 1,68$ & 2,00 & $0,43-8,29$ \\
\hline Ang-2 (ng/ml) & $1,4 \pm 0,3$ & 1,3 & $0,9-2,0$ \\
\hline TNF-a (pg/ml) & $12,59 \pm 5,29$ & 14,36 & $5,0-22,5$ \\
\hline TNF R1 (ng/ml) & $4,63 \pm 2,19$ & 4,08 & $1,40-12,98$ \\
\hline
\end{tabular}

Keterangan: $\mathrm{IMT}=$ indek masa tubuh; $\mathrm{HDL}=$ high density lipoprotein; $\mathrm{LDL}=$ low density lipoprotein; HOMA-IR $=$ homeostasis model assessment-insulin resistance; Ang-2= angiopoietin-2; TNF- $\alpha=$ tumor necrosis factor-alpha; TNFR= tumor necrosis alpha receptor-1

Tabel 2. Analisis mulltivariat peranan usia, tekanan darah, trigliserida, konsentrasi TNF- $\alpha$, TNFR1, dan Ang-2 plasma terhadap kejadian RI pada 81 penderita $\mathrm{Ob}-\mathrm{Ab}$

\begin{tabular}{llll}
\hline & \multicolumn{2}{l}{ Koefisien } & \\
\cline { 2 - 4 } & $\beta$ & $\mathrm{t}$ & Nilai $\mathrm{p}$ \\
\hline Ang-2 & 0,577 & 6,056 & 0,000 \\
TNF- $\alpha$ & 0,012 & 0,131 & 0,896 \\
TNFR1 & 0,068 & 0,717 & 0,476 \\
Usia & 0,025 & 0,303 & 0,763 \\
Sistolik & 0,088 & 0,386 & 0,700 \\
Diastolik & 0,078 & 0,338 & 0,737 \\
\hline
\end{tabular}

Keterangan: Ang-2=Angiopoietin-2; TNF $\alpha=$ tumor necrosis factor-alpha; TNFR1 = tumor necrosis alpha receptor-1

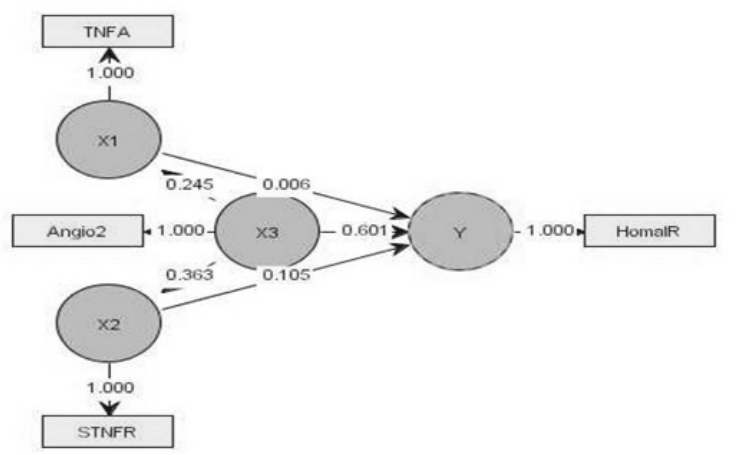

Gambar 1. Model analisis jalur (path-analysis) pengaruh TNF- $\alpha$, TNFR1, dan Ang-2 terhadap kejadian RI pada penderita $\mathrm{Ob}-\mathrm{Ab}$.

\section{PEMBAHASAN}

TNF- $\alpha$ menimbulkan aktivitas perubahan pada ekspresi adipokin melalui signaling inflamasi dan akan menimbulkan RI pada penderita Ob-Ab. ${ }^{[15]}$ Dengan demikian, terdapat indikasi bahwa $\mathrm{Ob}-\mathrm{Ab}$ berkorelasi dengan peningkatan inflamasi jaringan adiposa yang berkorelasi positif dengan kejadian RI. ${ }^{[16,17]}$ Penelitian lainnya melaporkan tidak terdapat korelasi antara sirkulasi TNF- $\alpha$ dengan kejadian $\mathrm{RI}^{\left[{ }^{[18]}\right.}$ Penelitian ini juga menemukan tidak adanya korelasi antara kadar TNF- $\alpha$ sirkulasi dengan kejadian RI. Perbedaan ini kemungkinan diakibatkan perbedaan cara pengambilan bahan antara jaringan dan plasma. TNF- $\alpha$ adalah bersifat parakrin, sehingga kadarnya akan berbeda jika diambil dari jaringan inflamasi dibandingkan plasma yang bersifat endokrin.

Setelah TNF- $\alpha$ berikatan dengan reseptornya (TNFR1 dan TNFR2) maka akan terjadi proteolisis bagian ektraseluler reseptor dengan menghasilkan bentuk yang mudah larut (soluble), yang dinamai sTNFR1 dan sTNFR2. ${ }^{[19]}$ Dengan demikian pemeriksaan aktivitas TNF- $\alpha$ di plasma berdasarkan kadar reseptornya lebih dapat dipercaya. Di dalam plasma protein ini sangat mudah dikenali dan mencerminkan derajat aktivitas TNF- $\alpha$ yang lebih akurat dibandingkan kadar TNF- $\alpha$ dalam sirkulasi. ${ }^{[20]}$ Beberapa penelitian melaporkan TNFR1 merupakan mediator utama untuk aktivitas biologis TNF- $\alpha$ pada kejadian RI dan DM 
tipe 2. ${ }^{[21,22]}$ Pada penelitian ini ditemukan korelasi positif bermakna kadar TNFR1 plasma dengan kejadian RI pada penderita $\mathrm{Ob}-\mathrm{Ab}$. Dari fakta ini kemungkin-an ikatan antara TNF- $\alpha$ dan TNFR1 akan menimbulkan aktivasi faktor transkripsi nuclear factor kappa beta (NF $\mathrm{B})$ dan janus kinase (JNK), yang akan menimbulkan hambatan signaling insulin melalui rangsangan fosforilasi serin/treonin insulin reseptor substrat(IRS)-1. ${ }^{[23]}$

Obesitas abdominal ditandai dengan adanya hipoksia jaringan adiposa. Pada keadaan hipoksia maka akan terjadi peningkatan proses angiogenesis untuk mempertahankan nutrisi jaringan adiposa. Proses angiogenesis ini ditandai dengan peningkatan faktor angiogenik seperti Ang2 disertai peningkatan respon inflamasi. ${ }^{[24]}$ Dengan demikian hubungan timbal balik antara angiogenesis dan inflamasi akan mempermudah untuk terjadinya RI pada obesitas. Lemak intraabdominal nampaknya sebagai sumber utama produksi Ang-2 yang terdapat pada sirkulasi. Beberapa penelitian melaporkan terdapat korelasi positif antara kadar Ang-2 plasma dengan peningkatan jumlah lemak intraabdominal. ${ }^{[25,26]}$ Meskipun mekanisme-nya belum jelas, bahwa Ang-2 yang dihasilkan oleh adiposit dapat mengatur aktivitas insulin dan berperan penting untuk timbulnya RI, dari beberapa penelitian dilaporkan bahwa terdapat korelasi positif bermakna antara kadar Ang-2 plasma dengan keadaan RI pada penderita Ob-Ab. ${ }^{[27,28]}$ Sesuai dengan penelitian tersebut, pada penelitian ini didapatkan juga adanya korelasi yang positif bermakna antara kadar Ang-2 plasma dan kejadian RI sistemik yang diperiksa menggunakan HOMA-IR.

Resistensi insulin pada penderita $\mathrm{Ob}-$ $\mathrm{Ab}$ merupakan kelainan metabolisme yang komplek dan heterogen. Hal tersebut timbul akibat dari kombinasi antara proses inflamasi dan angiogenesis. Inflamasi dan angiogenesis dapat bekerja secara langsung maupun tidak langsung untuk menimbulkan keadaan RI. ${ }^{[29]}$ Hasil penelitian ini menunjukkan bahwa faktor inflamasi TNF$\alpha$ maupun TNFR1 mempunyai pengaruh langsung yang tidak bermakna terhadap kejadian RI. Yang berbeda, bahwa kadar Ang-2 plasma pada penelitian mempunyai pengaruh secara konsisten terhadap kejadian RI, baik secara langsung maupun tidak langsung melalui pengaruh positif terhadap TNF- $\alpha$ maupun TNFR1. Dalam hal ini terdapat mata rantai antara kadar Ang-2 plasma dan keadaan inflamasi jaringan adiposa yang berhubungan dengan terjadinya RI sistemik pada penderita $\mathrm{Ob}$ $\mathrm{Ab}$.

Terdapat beberapa kelemahan dalam penelitian ini antara lain sampel yang kecil dan pemeriksaan kadar Ang-2 yang dilakukan hanya pada awal penelitian sehingga tidak menggambarkan kemungkinan adanya variasi dari parameter ini pada waktu berikutnya. Disamping itu, penentuan faktor-faktor risiko RI lainnya kurang lengkap dan ekslusi terhadap tidak diketahuinya RI untuk jangka waktu panjang kemungkinan kejadian yang tidak terduga.

\section{SIMPULAN}

Dari penelitian ini dapat disimpulkan bahwa kadar Ang-2 plasma secara bermakna dan konsisten berkorelasi dengan kejadian RI dan inflamasi pada penderita Ob-Ab. Dengan demikian adanya Ang-2 plasma dan inflamasi dijadikan penanda terjadinya $\mathrm{RI}$ pada penderita $\mathrm{Ob}-\mathrm{Ab}$.

\section{DAFTAR PUSTAKA}

1. Qatanani M, Lazar MA. Mechanism of obesity-associated insulin resistance: many choices on the menu. Genes \& Development 2007; 21: 1443-55.

2. Schenk S, Saberi M, Olefsky J M.Insulin sensitivity: modulation by nutritients and inflammation. J Clin Invest 2008; 118: 2992-3002.

3. Liang H, Yin B, Zhang H., Zhang S, Zeng Q, Wang, J, et al. Blockade of TNFR1-mediated TNF- $\alpha$ signaling protected Wistar rats from dietinduced obesity and insulin resistance. Endocrinology 2008; 149: 2943-51.

4. Shah A. Mehta N, Reilly M P. 
Adipose Inflammation, Insulin Resistance, and Cardiovascular Disease. Parenter Enteral Nutr 2008; 32: 638-44.

5. WeisbergSP, McCann D, DesaiM, Rossenbaun M, Leibel RL, Ferrante A W.Obesity is associated with macrophage accumulation in adiposa tissue. J Clin Invest 2003; 112: 17961808.

6. Lijnen $\mathrm{H}$ R. Angiogenesis and obesity. Cardio.Res 2010; 78: 286-93.

7. Tahergorabi Z, Khazaei M. The relationship between inflammatory markers, angiogenesis, and obesity. ARYA Atheroscler 2013; 9(4): 24753.

8. Imhof B A., Aurrand-Lions M. Angiogenesis and inflammation face off. Nat. Med 2006; 12: 171-72.

9. Fiedler U, Reiss Y, Scharpfenecker M, Grunow V, Koidl S, Thurston G. Angiopoietin-2 sensitizes endothelial cells to TNF-Alpha and has a crucial role in the induction of inflammation. Nat Med 2006; 12(2): 235-39.

10. Tabata M, Kadomatsu T, Fukuhara S, Miyata K, Ito $\mathrm{Y}$, Endo $\mathrm{M}$, et al. Angiopoietin-like Protein 2 Promotes Chronic Adipose Tissue Inflammation and Obesity-Related Systemic Insulin Resistance. Cell Metab 2009; 10: 17888.

11. Rasul S, Reiter M H, Ilhan A, Lampchler K, Wegner L, KautzkyWiller A. Circulating angiopoietin-2 and soluble Tie-2 in type 2 Diabetes mellitus: a cross-sectional study. Cardivascular Diabet 2011; 10: 55-61.

12. World Health Organization (WHO) Western Pacific Region. 2000. The Asia-Pacific perspective: Redifining Obesity and its treatment.

13. Chobanian A V, Bakris G L, Black H, Cushman W C, Green L A., Izzo $\mathrm{J}$ L, et al. National High Blood Pressure Education Program Coordinating Committee. The Seventh Report of the Joint National Committee on Prevention, Detection, Evaluation, and Treatment of High
Blood Pressure. JAMA 2003; 289: 2560-2572.

14. Matthews D R, Hosker J P, Rudenski A S, Naylor B A, Treacher D F, Turner R C. Homeostasis model assesment: Insulin resistance and beta -cell function from plasma glucose and insulin concentration in man. Diabetologia 1985; 28: 412-19.

15. Guilherme A, Virbasius JV, Puri V, Czech P. Adipocyte dysfunctions linking obesity to insulin resistance and type 2 diabetes. Mol Cel Biol 2008; 9: 367-77.

16. Ruan H, LodishH F. Insulin resistance in adiposa tissue: direct and indirect effects of tumor necrosis factor- $\alpha$. Cytokine \& Growth Factor 2003; 14 : 447-55.

17. Després J P, Lemieux I, Bergeron J, Pibarot P, Mathieu P, Larose E, et al. Abdominal Obesity and Metabolic syndrome: Contribution to Global Cardiometabolic Risk. Arterioscler ThrombVasc Biol 2008; 28: 1039-49.

18. Swaroop J J Rajarajeswari D, Naidu $\mathrm{J}$ N. Association of TNF- $\alpha$ with insulin resistance in type 2 diabetes mellitus. Indian J Med Res 2012; 135 (1): 127-30.

19. Cawthorn W P, Sethi J K. TNF- $\alpha$ and adipocyte biology. FEBS Lett 2008; 582: 117-131

20. Zahorska-Markiewicz B. Metabolic effects associated with adipose tissue distribution. Adv Med Sci 2006; 51: 111-14.

21. Uysal K, Wiesbrock M., Marino N W, Hotamisligil G S. Protection from obesity-induced insulin resistance in mice lacking $\mathrm{TNF}-\alpha$ function. Nature 1997; 389: 610-14.

22. Sethi J K, Xu H., Uysal K T., Wiesbrock S M, Scheja L, Hotamisligil GS. Characterisation of receptor-spesific TNF-alpha functions in adipocyte cell lines lacking type 1 and 2 TNF- $\alpha$ receptors. FEBS Lett 2000; 469: 77-82.

23. Shoelson S E, Lee J, Goldfine A B. Inflammation and insulin resistance. $\mathrm{J}$ 
Clin Invest 2006; 116: 1793-1801

24. Muramoto A, Tsushita K, Kato A, Ozaki N, Tabata $M$, Endo $M$, et al. Angiopoietin-like protein 2 sensitively respond to wight reduction induced by lifestyle intervention on overweight Japanese men. Nutrition and Diabetes 2011; 16: 1038-48.

25. Silha J V, Krisek M, Sucharda P, Murphy L J. Angiogenic factors are elevated in overweight and obese individuals. Int J Obes 2005; 29: 1308 $-14$.

26. Ye J. Adipose Tissue Vascularization: Its Role in Chronic Inflammation. Curr Diab Rep. 2011; 11(3); 203-210.

27. Rasul S, Reiter M H, Ilhan A, Lampchler K., Wegner L, KautzkyWiller A. Circulating angiopoietin-2 and soluble Tie-2 in type 2 Diabetes mellitus: a cross-sectional study. Cardivascular Diabet 2011; 10: 55-61.
28. Kota S K, Meher L K, Jammula S, Kota S K, Khrismna S V S, Modi K D. Abberant angiogenesis: The gateway to diabetic complication. IJEM 2014; 16: 918-30.

29. Doi Y, Ninomiya T, Hirakaya Y, Takahashi Y, Naoko M, Hata J, et al. Angiopoietin-Like Protein-2 and Risk of Type2 Diabetes in a General Japanese Population.The Hisayama Study. Diabetes Care 2013; 36: 98100. 